\title{
Financial Report
}

\author{
Dr. George Ledingham
}

We thought you might be interested in how your magazine is getting along financially. If you are like the little girl whose reports showed all A's you won't be interested in your progress. You remember her remark: "Isn't it boring, Mama."

For those who are interested, we are pleased to report that we have 1283 paid-up members. This is the first time we've had over 1000 members. We ordered 1050 copies in December so as to have extras, but we had only 788 members at that time. (The Museum takes 200 copies for distribution.) We were operating at a loss in October 1952 as reported at the annual meeting. It was decided at that time that although it cost $\$ 1.12$ to send out four copies, we would not raise the price but do our best to get new members. So you see we are delighted that the picture has changed.

Much good work has been done. First mention must go to our president, Dr. Stuart Houston who has sent out hundreds of letters and buttonholed scores of his friends. As a result of his work the magazine is going into Manitoba and Alberta. We may have te change our name one day to Prairie Natural History Society. Our second Vice-President, Mr. Jack Shaver, has sent in long lists of members from various points visited in his travels. Third mention, if we limit ourselves to three, should go to Mrs. John Hubbard, a former director of the Society. She wrote letters to five papers and two radio stations, and many people learning that they were not the only ones interested in nature and conservation joined the Society. Special thanks should go to the Western Producer and the Saskatchewan Farmer for encouraging articles. We would like to thank everyone who has helped by getting new members, or with the collection of renewal dues.

This collection of renewals is a grave problem. People forget to send in the necessary dollar. Last year we sent three issues and when some subscribers still forgot we had to drop 107 names from our list. This year we did not send magazines to those who did not renew their subscriptions and 135 names were dropped. We are hoping many of these will miss the Blue Jay and send in a dollar. We still have 250 copies of the last issue and can start a subscription with this one for the first 250 new members. In this way they will receive all 1953 numbers.

\section{Notice to Subscribers:}

At the last annual meeting its was decided that members sending in five gift subscriptions became patrons just as members do who give cash donations of five dollars. Please state clearly in your letter whether or not you are sending gift subscriptions, and if you have been overlooked in the list of patrons, please let us know.

\section{Additional Patrons for 1953}

Ed Brooman, Prince Albert

Arthur Ward, Swift Current 